\title{
Resusitasi Cairan pada Cedera Kepala
}

\author{
Nurma Afiani, S.Kep., Ners., M.Kep. \\ nurmaafiani@gmail.com \\ Program Studi S1 Ilmu KeperawatanSTIKES Widyagama Husada
}

\begin{abstract}
Head injury is one of the trauma cases that require certain attention in resuscitation fluid. The amount and type of the fluid in resuscitation should be carefully and appropriately noted; the fluid used should be able to control the intracranial pressure in the brain, decrease the cerebral edema, and avoid the negative side effects to other organs. The amount and type and of the resuscitation fluid in head injury still becomes controversial topic so that the literature about this case is limited. This study aimed at revealing the amount and type and of the resuscitation fluid in head injury based on the related previous studies in EBSCO, PROQUEST, and CENGANGE in the last 10 years. The keywords related to this are 'resuscitation', 'intracranial pressure', 'head injury', 'traumatic brain injury' and 'head trauma'. The articles were selected based on the appropriateness of the topic and the purpose in this study which is to identify the amount and type and of the resuscitation fluid. The findings showed that there is no type of resuscitation fluid that is ideally appropriate to be used in any trauma cases. The methods of delivery including the time, the volume, and the purpose, are more important than the type itself. Hypertonic saline solution (HTS) is one of the resuscitation fluid types that can be used in several alternative dosages: $3 \% \mathrm{HTS} 3 \mathrm{ml} / \mathrm{kg}$ secara IVfor 10-20 minutes; two bolus $250 \mathrm{ml} 5 \%$ HTS or $500 \mathrm{ml} \mathrm{3 \%} \mathrm{HTS;} \mathrm{4-5ml/kg} \mathrm{HTS.} \mathrm{HTS}$ as one of the resuscitation fluid typesis excellent in decreasing the cerebral edema and has the quality as reno-protective agent.
\end{abstract}




\begin{abstract}
ABSTRAK
Cedera kepala merupakan salah satu kasus trauma yang memerlukan perhatian khusus dalam resusitasi cairan. Jumlah dan jenis cairan yang digunakan dalam proses resusitasi cedera kepala harus diperhatikan secara cermat, cairan yang digunakan harus mampu mengontrol tekanan intrakranial (TIK) otak, dapat mengurangi edema otak dan tidak menimbulkan efek samping bagi organ tubuh yang lain. Jenis dan jumlah cairan resusitasi pada kasus cedera kepala masih menjadi topik kontroversial sehingga literatur mengenai cairan resusitasi pada kasus cedera kepala masih terbatas. Artikel berikut ini akan menyajikan jenis dan jumlah cairan yang tepat untuk resusitasi cedera kepala berdasarkan review hasil penelitian terkait yang disajikan dalam EBSCO, PROQUEST, CENGANGE dalam rentang 10 tahun terakhir. Kata kunci yang digunakan adalah 'fluid resusication', 'intracranial pressure', 'head injury', 'traumatic brain injury', 'head trauma'. Artikel diseleksi berdasarkan kesesuaiannya dengan tujuan yakni mengidentifikasi jenis dan jumlah cairan resusitasi. Hasil review menunjukkan bahwa tidak ada suatu jenis cairan resusitasi 'ideal' yang dapat digunakan untuk semua kasus trauma. Metode pemberian cairan (waktu, volume dan tujuan yang diharapkan) lebih penting dibandingkan dengan jenis cairan itu sendiri. Hypertonis saline solution (HTS) menjadi salah satu jenis cairan resusitasi yang dapat digunakan dengan beberapa pilihan dosis sebagai berikut: $3 \%$ HTS $3 \mathrm{ml} / \mathrm{kg}$ secara IV selama $10-20$ menit; dua bolus $250 \mathrm{ml} 5 \%$ HTS atau $500 \mathrm{ml}$ $3 \%$ HTS; $4-5 \mathrm{ml} / \mathrm{kg}$ HTS. HTS sebagai cairan resusitasi cedera kepala unggul dalam menurunkan edema otak dan tidak menimbulkan efek berbahaya bagi organ lain (renoprotective agent).
\end{abstract}

\section{PENDAHULUAN}

Resusitasi cairan merupakan salah satu unsur penting dalam penatalaksanaan kasus trauma. Tujuan utama dilakukannya resusitasi cairan pada kasus trauma adalah untuk mencegah terjadinya hipotermia, asidosis, dan koagulopati yang dapat mengakibatkan kerusakan organ lebih lanjut (Burch et al., 1992 dalam Levett, 2006). Pemberian jumlah dan jenis cairan resusitasi yang tepat dapat menurunkan resiko kerusakan organ irreversibel akibat hipoperfusi jaringan. Kriteria standart jenis cairan resusitasi adalah cairan yang tidak memiliki efek samping bagi seluruh organ tubuh, namun sampai saat ini belum tersedia jenis cairan 'ideal' tersebut (Levett, 2006; Vercueil, 2006)

Cedera kepala merupakan salah satu kasus trauma yang memerlukan perhatian khusus dalam resusitasi cairan. Jumlah dan jenis cairan yang digunakan dalam proses resusitasi cedera kepala harus diperhatikan secara cermat, cairan yang digunakan harus mampu mengontrol tekanan intra kranial (TIK) otak, dapat mengurangi edema otak dan tidak menimbulkan efek samping bagi organ tubuh yang lain. Dalam tinjauan konsep berikut akan disampaikan beberapa hal mengenai cedera kepala meliputi: definisi, proses patofisiologi, managemen cedera kepala dan jenis cairan resusitasi pada kasus trauma. Sedangkan pada bagian pembahasan akan diulas jenis dan jumlah cairan yang tepat untuk resusitasi cedera kepala.

\section{TINJAUAN KONSEP \\ Definisi Cedera Kepala}

Cedera jaringan otak (Traumatic Brain Injury) merupakan istilah yang digunakan untuk menunjukkan adanya cedera kepala yang disertai dengan cedera pada jaringan otak (didukung hasil CT-Scan otak). Sedangkan cedera kepala merupakan istilah umum yang menunjukkan adanya trauma pada area kepala. Hasil konsensus menyebutkan bahwa cedera kepala merupakan istilah yang digunakan untuk semua pasien dengan indikasi mengalami trauma pada kepala berdasarkan hasil pemeriksaan fisik (Schutzman dalam Berger and David, 2005). 
Status neurologis pasien yang diukur dengan Glasgow Coma Scle (GCS) merupakan salah satu cara pengklasifikasian tingkat keparahan cedera kepala. Skor GCS $<8$ mengindikasikan cedera kepala berat, skor GCS 9-12 mengindikasikan cedera kepala sedang dan skor GCS 13-15 mengindikasikan cedera kepala ringan. Penggunaan GCS pada anak sulit mengindikasikan kondisi keparahan cedera kepala karena sulit mengkaji respon verbal anak. Untuk mengatasi hal tersebut maka dikembangkan The Infant Face Scale (IFS), namun sayangnya penggunaan IFS ini belum terstandarisasi. Dalam keterbatasannya GCS pada anak tetap digunakan sebagai salah satu cara pengklasifikasian tingkat keparahan pasien anak dengan cedera kepala (Berger and David, 2005).

\section{Patofisiologi Cedera Kepala}

Proses patofisiologi cedera kepala dibedakan menjadi dua bagian yaitu: Primary Brain Injury dan Secondary Brain Injury. Berikut ini akan dibahas secara lebih mendalam proses patofisiologi pada cedera kepala:

\section{Primary Brain Injury}

Primary Brain Injury merupakan kerusakan otak tahap pertama yang diakibatkan oleh proses mekanik (Japardi, 2002). Proses patofisiologi Primary Brain Injury dibedakan menjadi dua yakni: lesi focal dan diffuse. Lesi focal dapat diakibatkan oleh adanya benturan pada kepala sehingga dapat menimbulkan contusio dan hematom. Sedangkan lesi diffuse sering diakibatkan benturan akibat kecelakaan lalu lintas (Mark et all, 2002). Tingkat keparahan lesi ditentukan oleh lokasi dan kekuatan mekanik benturan (Mark et all, 2002) (Japardi, 2002), arah, kondisi kepala, dan percepatan gerak kepala (Japardi, 2002). Beberapa tipe primary brain injury antara lain: fraktur tengkorak, epidural hematom, subdural hematom, intracerebral hematom, diffuse axonal injury.

\section{Secondary Brain Injury}

Secondary Brain Injury merupakan kerusakan neuron yang diakibatkan oleh adanya respon sistemik fisiologis yang muncul akibat adanya cedera (Mark et all, 2002). Struktur anatomi dan fisiologi otak yang berubah dapat mengakibatkan meluasnya perdarahan, edema otak, kerusakan neuron berlanjut, iskemia fokal/ global otak, kejang dan hipertermi (Japardi, 2002).

Dalam waktu 24 jam pertama setelah kejadian cedera, aliran darah otak (cerebral blood flow) berkurang hingga lebih dari separuh aliran darah otak normal (Mark et all, 2002). Sebagai akibatnya otak dapat mengalami iskemia dan pada akhirnya dapat menimbulkan hipotensi. Survey yang dilakukan pada korban meninggal akibat cedera kepala menunjukkan bahwa lebih dari $80 \%$ pasien meninggal tersebut mengalami posttraumatic ischemic lession (Mark et all, 2002).

\section{Managemen Cedera Kepala}

Pasien dengan cedera kepala harus mendapatkan penanganan segera untuk mencegah terjadinya cedera kepala sekunder. Pasien dengan cedera kepala harus ditangani dan diobservasi secara teratur sejak dari lokasi kejadian, selama perjalanan dari lokasi kejadian sampai rumah sakit, di ruang gawat darurat, kamar radiologi, ruang operasi, ruang perawatan atau ICU. Observasi yang terus menerus dilakukan bertujuan untuk mengevaluasi kondisi pasien yang terkadang dapat memburuk akibat aspirasi, hipotensi, dan kejang.

\section{Primary Trauma Survey}

Tujuan utama perawatan pasien pada fase pre-hospital adalah menstabilkan fungsifungsi vital, pencegahan hipotensi dan 
hipoksia (Procaccio, et all, 2000). Prioritas utama pada tahap primary survey adalah stabilisasi servical, patensi jalan nafas $(A$, airway), ventilasi pernafasan ( $B$, breathing), mendapatkan akses vena untuk resusitasi cairan $(C$, circulation), pengkajian tingkat kesadaran dan pupil (D, disability) (Mark et all, 2002).

\section{Airway (A)}

Pasien dengan skor GCS (Glasgow Coma Scale) kurang dari 8 harus dilakukan intubasi, diawali dengan pemberian sedasi. Rekomendasi sedasi yang diberikan sebagai berikut: Thiopental sodium 2-3 $\mathrm{mg} / \mathrm{kg}$ i.v atau propofol $1-2 \mathrm{mg} / \mathrm{kg}$ i.v atau midazolam 0,2-0,3 $\mathrm{mg} / \mathrm{kg}$. Jika pasien mengalami hipotensi atau perdarahan maka diberikan terapi: ketamine $1 \mathrm{mg} / \mathrm{kg}+$ thiopental $1 \mathrm{mg} / \mathrm{kg}$ atau midazolam 0,05-0,1 $\mathrm{mg} / \mathrm{kg}$. Berikan juga succinylcholine 1 $\mathrm{mg} / \mathrm{kg}$ i.v atau vecuronium $0,1 \mathrm{mg} / \mathrm{kg}$ i.v. Pemberian sedasi dan analgesik short-acting digunakan agar fungsi neurologis tetap dapat terpantau dengan interval yang teratur. Jika memungkinkan muscle relaxing digunakan seminimal mungkin (Procaccio et all, 2000).

\section{Breathing (B)}

Ventilasi yang adekuat harus dilakukan pada semua pasien yang diintubasi dengan tujuan: oksigenasi adekuat $\left(\mathrm{PaCO}_{2}\right.$ $\left.>90 \mathrm{mmHg}, \quad \mathrm{SaO}_{2}>95 \%\right)$ dan mencegah terjadinya hypercapnia maupun hypocapnia $\left(\mathrm{PaCO}_{2}\right.$ 30-35 mmHg). Kondisi hypercapnia harus dicegah karena dapat mengakibatkan asidosis cerebral dan vasodilatasi yang dapat menimbulkan hipertensi dan kerusakan otak sekunder. Kondisi hiperventilasi juga harus dihindari karena dapat menimbulkan hypocapnia yang dapat mengakibatkan vasokonstriksi pembuluh darah otak sehingga aliran darah ke otak semakin berkurang (Procaccio et all, 2000).

\section{Circulation (C)}

Kondisi hipotensi setelah cedera (tekanan darah sistolik $<90 \mathrm{mmHg}$ ) dapat meningkatkan angka kecacatan dan kematian pada pasien dengan cedera kepala. Oleh karena itu untuk menjaga adekuatnya aliran darah otak (cerebral perfusion presusure) maka tekanan darah sistolik harus dipertahankan $>110 \mathrm{mmHg}$ pada dewasa. Beberapa langkah yang dilakukan untuk mencapai tekanan darah sistolik $>110 \mathrm{mmHg}$ antara lain: (1) periksa adanya perdarahan eksternal dan segera lakukan pembebatan, (2) pasang IV line dengan ukuran 16G, (3) lakukan resusitasi awal dengan pemberian cairan isotonis (saline, ringer laktat), (4) hindari pemberian cairan hipotonis, (5) pemberian diuretik seperti manitol tidak dianjurkan (Procaccio et all, 2000).

\section{Disability (D)}

Metode pemeriksaan status neurologis pasien cedera kepala antara lain dengan: Glasgow Coma Scale (GCS), pengukuran diameter pupil dan reflek pupil terhadap rangsangan cahaya. Penilaian GCS didasarkan atas 3 komponen yang meliputi: respon mata, verbal dan motorik. Beberapa hal yang harus diperhatikan saat melakukan pengukuran skor GCS antara lain: (1) jika pasien mendapatkan terapi sedasi maka pengukran GCS dilakukan 1020 menit setelah waktu paruh obat, (2) jika pasien mengalami edema periorbital maka skor untuk mata adalah 1 ( $E=1)$, jika pasien terpasang ETT maka skor untuk verbal adalah $1(\mathrm{~V}=1)$, (3) stimulasi verbal selalu dilakukan sebelum stimulasi nyeri, (4) pertimbangkan kemungkinan terjadinya cedera spinal maupun cedera saraf perifer (Procaccio et all, 2000).

\section{Jenis Cairan Resusitasi}

Resusitasi cairan merupakan bagian integral dari resusitasi pada kasus cedera. Cairan resusitasi yang ideal harus memiliki beberapa kriteria seperti: dapat mengangkut oksigen, memiliki sedikit efek 
atau bahkan tidak memiliki efek terhadap proses koagulasi, murah, mudah didapat, bersifat non-alergic dan mampu bertahan pada suhu ruangan (Adewale, 2009). Beberapa jenis cairan resusitasi yang tersedia saat ini antara lain kristaloid, koloid dan beberapa produk darah (Rudra, et all, 2006):

\section{Hipertonic Saline Solutions}

Indikasi penggunaan hipertonic saline: digunakan sebagai osmotherapic agent pada kasus edema cerebral, dapat mengurangi gejala hyponatremic seizures, dalam jumlah kecil digunakan sebagaii terapi pada kasus cedera kepala, berperan sebagai renoprotective agent (mencegah terjadinya cytotoxic nepropathy, rhabdomyolisis yang dapat mengakibatkan gagal ginjal) (STRS, 2011).

Mekanisme kerja hipertonic saline: mengakibatkan perpindahan cairan dari \begin{tabular}{lcr} 
intraseluler & menuju & \multicolumn{2}{c}{ ekstraseluler, } \\
menurunkan & jumlah cairan & otak, \\
meningkatkan & volume & darah, \\
meningkatkan & sodium & plasma.
\end{tabular} Keuntungan penggunaan hipertonic saline: baik digunakan untuk kasus cedera kepala terutama pada pasien anak dengan plasma sodium $170 \mathrm{mmol} / \mathrm{L}$ untuk mengontrol ICP, memiliki efek 'rebound' yaitu mudah dikeluarkan dari interstisial, hipertonic saline bersifat 'reno-protective', hipertonic saline secara cepat dapat meningkatkan kadar $\mathrm{Na}$ sehingga kontrol dapat dengan mudah dilakukan yakni dengan cek kadar Na dalam plasma. Dosis yang digunakan: dosis standart yakni $3 \mathrm{ml} / \mathrm{kg} 3 \%$ saline (diberikan 10-20 menit) melalui vena cetral atau vena perifer, $3 \mathrm{ml} / \mathrm{kg} 3 \%$ saline dapat meningkatkan kadar $\mathrm{Na}$ plasma 2-3 $\mathrm{mmol} / \mathrm{L}$. Pada gambar dibawah ini akan dijelaskan bagaimana teknik menyiapkan saline 3\% dari saline 30\% (STRS, 2011).

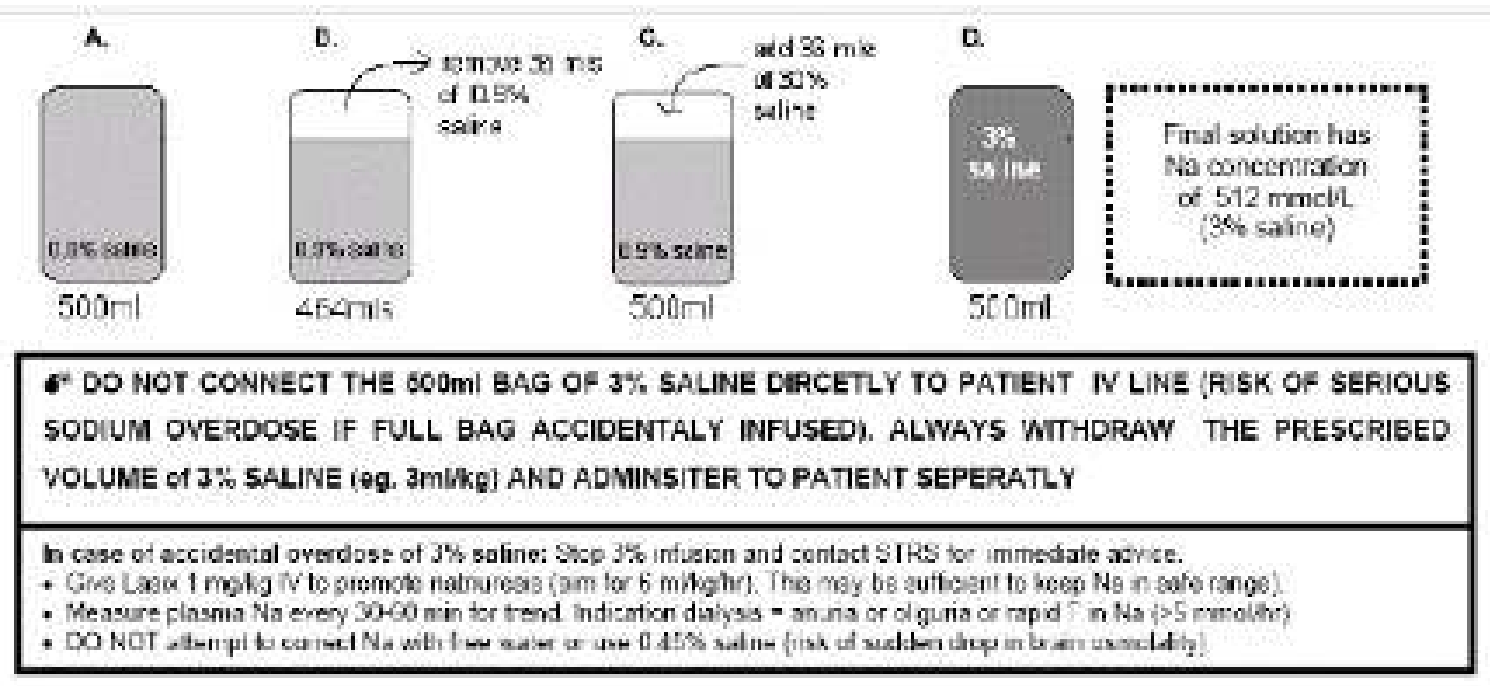

Gambar 1: Membuat saline 3\% dari saline 30\%

\section{Darah}

Penggunaan darah sebagai cairan resusitasi memiliki keunggulan yakni dapat membantu proses transport oksigen. Namun hanya sedikit pendapat yang menunjukkan bahwa darah dapat digunakan sebagai alternatif cairan resusitasi. Sebelum menggunakan darah sebagai pilihan cairan resusitasi harus dilakukan pencocokan golongan darah, dimana diperlukan pengambilan sampel darah dari pasien yang memerlukan cukup waktu. Selain itu proses transfusi darah yang masivve dapat mengakibatkan dilutional coagulopathy, hypocalcemia dan hypomagnesemia. Transfusi darah juga berpotensi menularkan beberapa bakeri 
patogen seperti hepatitis dan HIV (Rudra et all, 2006).

\section{Hemoglobin solutions}

Hemoglobin solutions merupakan salah satu jenis cairan resusitasi yang diharapkan dapat memenuhi kriteria nonantigenic, bebas bakteri maupun virus pembawa penyakit, dan mampu mengangkut oksigen. Hemoglobin bebas yang digunakan sebagai cairan resusitasi dapat mengakibatkan cedera akut pada ginjal. Oleh karena itu, bentuk sediaan hemoglobin sebagai bahan yang siap digunakan sebagai cairan resusitasi masih terus diteliti (Rudra et all, 2006).

\section{Albumin}

Albumin merupakan polipeptida single yang memiliki berat molekul 65-69 kDa. Albumin berperan dalam proses transport dan penyusun integritas mikrovaskular. Melalui proses produksi sediaan albumin kini bebas dari berbagai resiko tercemar bakteri (Rudra et all, 2006).

\section{Koloid}

Koloid adalah suatu campuran zat heterogen antara dua zat atau lebih di mana partikel-partikel zat yang berukuran koloid tersebar merata dalam zat lain. Ukuran koloid berkisar antara 1-100 nm ( 10-7 - 10-5 cm ) (Rudra et all, 2006).

\section{Kristaloid}

Larutan kristaloid adalah larutan air dengan elektrolit dan atau dextrosa, tidak mengandung molekul besar (Adewale, 2009). Kristaloid dalam waktu singkat sebagian besar akan keluar dari intravaskular, sehingga volume yang diberikan harus lebih banyak (2,5-4 kali) dari volume darah yang hilang (Rudra et all, 2006). Kristaloid mempunyai waktu paruh intravaskuler 20-30 menit. Ekspansi cairan dari ruang intravaskuler ke interstital berlangsung selama 30-60 menit sesudah infus dan akan keluar dalam 24-48 jam sebagai urine (Mulyono, 2006).Secara umum kristaloid digunakan untuk meningkatkan volume ekstrasel dengan atau tanpa peningkatan volume intrasel (Tonessen AS., 1990). Macam-macam cairan kristaloid antara lain (Tonessen AS., 1990):

\begin{tabular}{lcccccc}
\hline Cairan & $\begin{array}{c}\mathrm{Na}^{+} \\
(\mathbf{m E q} / \mathrm{L})\end{array}$ & $\begin{array}{c}\mathrm{K}^{+} \\
(\mathbf{m E q} / \mathrm{L})\end{array}$ & $\begin{array}{c}\mathrm{Cl}^{-} \\
(\mathbf{m E q} / \mathrm{L})\end{array}$ & $\begin{array}{c}\mathrm{Ca}^{++} \\
(\mathbf{m E q} / \mathrm{L})\end{array}$ & $\begin{array}{c}\mathrm{HCO}_{3} \\
(\mathbf{m E q} / \mathrm{L})\end{array}$ & $\begin{array}{c}\text { Tek. } \\
\text { Osmotik } \\
(\mathbf{m O s m} / \mathrm{L})\end{array}$ \\
\hline $\begin{array}{l}\text { Ringer } \\
\text { Laktat }\end{array}$ & 130 & 4 & 190 & 3 & $28^{*}$ & 273 \\
$\begin{array}{l}\text { Ringer } \\
\text { Asetat }\end{array}$ & 130 & 4 & 109 & 3 & $28^{\sharp}$ & 273 \\
$\mathrm{NaCl}$ & 154 & 0 & 0 & 0 & 0 & 308 \\
$0,9 \%$ & & & & & &
\end{tabular}

*sebagai laktat $\quad$ "sebagai asetat

Tabel 1: Macam-macam Cairan Kristaloid

Cairan kristaloid cukup baik untuk terapi syok hipovolemik. Keuntungan cairan kristaloid antara lain mudah tersedia, murah, mudah dipakai, tidak menyebabkan reaksi alergi dan sedikit efek samping. Kelebihan cairan kristaloid pada pemberian dapat berlanjut dengan edema 
seluruh tubuh sehingga pemakaian berlebih perlu dicegah (Martin, 2005).

Larutan $\mathrm{NaCl}$ isotonis dianjurkan untuk penanganan awal syok hipovolemik dengan hiponatremik, hipokhloremia atau alkalosis metabolik. Larutan RL adalah larutan isotonis yang paling mirip dengan cairan ekstraseluler. RL dapat diberikan dengan aman dalam jumlah besar kepada pasien dengan kondisi seperti hipovolemia dengan asidosis metabolik, kombustio dan sindroma syok. $\mathrm{NaCl} 0,45 \%$ dalam larutan Dextrose $5 \%$ digunakan sebagai cairan sementara untuk mengganti kehilangan cairan insensibel (Martin, 2005).

Ringer asetat memiliki profil serupa dengan Ringer Laktat. Tempat metabolisme laktat terutama adalah hati dan sebagian kecil pada ginjal, sedangkan asetat dimetabolisme pada hampir seluruh jaringan tubuh dengan otot sebagai tempat terpenting. Penggunaan Ringer Asetat sebagai cairan resusitasi patut diberikan pada pasien dengan gangguan fungsi hati berat seperti sirosis hati dan asidosis laktat. Adanya laktat dalam larutan Ringer Laktat membahayakan pasien sakit berat karena dikonversi dalam hati menjadi bikarbonat (Darmawan, 1999).

\section{PEMBAHASAN}

Cedera kepala merupakan salah satu kasus trauma yang memerlukan perhatian khusus dalam resusitasi cairan. Jumlah dan jenis cairan yang digunakan dalam proses resusitasi cedera kepala harus diperhatikan secara cermat. Tujuan utama penatalaksanaan pasien dengan cedera kepala adalah mencegah terjadinya hipotensi, menjaga cerebral perfusion presure (CPP) dalam rentang normal (Adewale $e t$ al., 2009; Rudra et al., 2006), Mean Arterial Pressure (MAP) dalam rentang normal, Intra Cranial Pressure (ICP) terkontrol (Adewale, 2009). Resusitasi cairan harus dilakukan sesegera mungkin setelah trauma untuk membantu memenuhi kebutuhan perfusi jaringan bahkan dapat dimulai sesegera mungkin saat korban masih berada di lokasi kejadian (Rudra et al., 2006). Pada sebuah studi prospektif disebutkan bahwa dari 717 pasien cedera kepala dengan tekanan darah sistolik $<90 \mathrm{mmHg}$ terkait dengan mortalitas sebesar 150\% (Chesnut et al., 1993 dalam Levett et al., 2006). Hal ini memperkuat fakta bahwa resusitasi cairan yang kurang tepat dapat memperburuk prognosis pasien dengan cedera kepala.

Resusitasi cairan merupakan bagian integral dari resusitasi pada kasus cedera kepala. Cairan resusitasi yang ideal harus memiliki beberapa kriteria seperti: dapat mengangkut oksigen, memiliki sedikit efek atau bahkan tidak memiliki efek terhadap proses koagulasi, murah, mudah didapat, bersifat non-alergic dan mampu bertahan pada suhu ruangan (Adewale et al., 2009). Namun tidak ada suatu jenis cairan resusitasi 'ideal' yang dapat digunakan untuk semua kasus trauma. Metode pemberian cairan (waktu, volume dan tujuan yang diharapkan) terkadang menjadi lebih penting dibandingkan dengan jenis cairan itu sendiri (Vercueil et al., 2006).

Berdasarkan tinjauan konsep mengenai jenis-jenis cairan resusitasi terkait dengan kasus cedera kepala diatas dapat disimpulkan bahwa: koloid tidak direkomendasikan sebagai cairan resusitasi pada cedera kepala karena tidak dapat menurunkan tekanan intrakranial dikarenakan kapiler cerebral impermiabel terhadap sebagian besar ion. Selain itu koloid juga dapat menimbulkan reaksi anaphyllactoid (Mark et all, 2002). Cairan isotonik juga tidak direkomendasikan karena dapat meningkatkan edema cerebral. Sedangkan produk darah kurang tepat digunakan sebagai cairan resusitasi pada kasus trauma karena beresiko menularkan beberapa penyakit dan memerlukan tahap persiapan yang lama seperti pengambilan sampel darah pasien dan pencocokan golongan darah dengan 
donor (Levett et al., 2006). Hypertonic saline solution disarankan untuk digunakan sebagai cairan resusitasi pada kasus cedera kepala (Levett et al., 2006; Mark et al.,2002). Hypertonic saline solution aman dan efektif digunakan untuk menurunkan tekanan intra kranial (TIK) (Adewale, 2009).

Cairan hypertonic saline solution memiliki beberapa manfaat jika digunakan pada pasien dengan cedera kepala antara lain: dapat menurunkan tekanan intracranial dan dapat meningkatkan kontraktilitas jantung (Mark et al., 2002). Pada fase pre-hospital pemberian hypertonic saline solution sebanyak $4-5 \mathrm{ml} / \mathrm{kg}$ terbukti dapat meningkatkan MAP (Mean Arterial Pressure) dan CO (Cardiac Output). Selain itu juga dapat meningkatkan aliran darah menuju organ tubuh lain seperti ginjal, mesenteric, splanchnic dan koroner (Rudra et al., 2006). Hasil penelitian yang dilakukan oleh Wade menyimpulkan bahwa penggunaan hypertonic saline solution sebagai cairan resusitasi pada pasien cedera kepala signifikan dapat meningkatkan survival rate (odds ratio, 2.12; $\mathrm{p}=0$,048) (Wade 1997 dalam Mark et all, 2002).

Dosis pemberian hypertonic saline solution (HTS) pada pasien dengan cedera kepala bervariasi menurut beberapa literatur. Menurut Rudra et al., 2006 pemberian HTS sebanyak $4-5 \mathrm{ml} / \mathrm{kg}$ terbukti dapat meningkatkan MAP. Adewale, et al merekomendasikan dua bolus $250 \mathrm{ml} 5 \%$ HTS atau $500 \mathrm{ml} 3 \%$ HTS sebagai terapi untuk hipertensi intrakranial pada pasien cedera kepala. Sedangkan South Thames Retrieval Services (STRS) menyebutkan dosis resusitasi cairan untuk cedera kepala adalah $3 \mathrm{ml} / \mathrm{kg} 3 \%$ saline (diberikan 10-20 menit) melalui vena cetral atau vena perifer, dimana $3 \mathrm{ml} / \mathrm{kg} 3 \%$ saline dapat meningkatkan kadar Na plasma 2-3 $\mathrm{mmol} / \mathrm{L}$.

Penggunaan hypertonic saline solution sebagai cairan resusitasi pada kasus cedera kepala selain banyak memberikan keuntungan juga dapat menimbulkan beberapa efek merugikan jika tidak dilakukan evaluasi ketat pada pasien. Efek merugikan yang dapat muncul saat pemberian hypertonic saline solution antara lain hypernatremia, metabolik asidosis, dan resiko terjadinya edema pulmonal (Rudra et al., 2006). Untuk meminimalkan terjadinya efek samping penggunaan HTS sebagai cairan resusitasi dapat ditekan dengan melakukan monitor ketat tanda-tanda vital pasien, kaji tingkat kesadaran pasien tiap 10-15 menit, lakukan pengukuran tekanan intra kranial pasien dan lakukan monitor kadar $\mathrm{Na}$ dalam plasma. Jika terjadi overdosis dalam pemberian HTS maka langkah yang dapat dilakukan adalah segera hentikan pemberian HTS, berikan lasix $1 \mathrm{ml} / \mathrm{kg}$ IV untuk membantu natriuresis (hingga urine output mencapai $6 \mathrm{ml} / \mathrm{kg} / \mathrm{jam}$ ), ukur kadar Na plasma tiap 30-60 menit sekali, lakukan dialisis jika terjadi oliguria/ anuria/ terjadi peningkatan kadar Na plasma secara cepat mencapai $>5 \mathrm{mmol} /$ jam dan jangan gunakan $0,45 \%$ saline sebagai terapi karena dapat menurunkan osmolaritas cairan otak secara tiba-tiba (STRS, 2011).

\section{KESIMPULAN}

Resusitasi cairan merupakan salah satu unsur penting dalam penatalaksanaan pasien cedera kepala. Tidak ada suatu jenis cairan resusitasi 'ideal' yang dapat digunakan untuk semua kasus trauma. Metode pemberian cairan (waktu, volume dan tujuan yang diharapkan) terkadang menjadi lebih penting dibandingkan dengan jenis cairan itu sendiri. Pada kasus cedera kepala penggunaan hypertonis saline solution sebagai cairan resusitasi dapat memberikan manfaat bagi pasien diantaranya membantu menurunkan edema otak dan tidak menimbulkan efek berbahaya bagi organ lain (renoprotective agent). Dosis pemberian hypertonis saline solution menurut beberapa sumber antara lain: 3\% HTS3ml $/ \mathrm{kg}$ secara IV selama 10-20 
menit (STRS, 2011), dua bolus 250ml 5\% HTS atau $500 \mathrm{ml} \mathrm{3 \%} \mathrm{HTS} \mathrm{(Adewale,} \mathrm{et} \mathrm{al.,}$ 2009), 4-5ml/kg HTS (Rudra et al., 2006). Hal terpenting yang harus diperhatikan perawat dalam pemberian HTS antara lain monitor ketat tanda-tanda vital pasien, kaji tingkat kesadaran pasien tiap 10-15 menit, lakukan pengukuran tekanan intra kranial pasien dan lakukan monitor kadar $\mathrm{Na}$ dalam plasma tiap 30-60 menit.

\section{REFERENSI}

Adewale, Ademola. (2009). Fluid Management in Adult and Pediatric Trauma Patients. Journal of Medical Sciences--Orthopedics And Traumatology.

Berger, Rachel Pardes, P. David Adelson. (2005). Evaluation and Management of Pediatric Head Trauma in the Emergency Departement: Current Concepts and State-of-the-Art Research. Clinical Pediatric Emergency Medicine. 6:(8-15). Elsevier Inc.

Darmawan, Iyan, MD, Cairan Alternatif untuk Resusitasi Cairan: Ringer Asetat, Medical Departement PT. Otsuka Indonesia, Simposium Alternatif Baru Dalam Terapi Resusitasi Cairan. Bagian Anestesiologi FKUI/RSCM, Jakarta, 14 Agustus 1999.

Japardi, Iskandar. (2002). Penatalaksanaan Cedera Kepala Akut. USU Digital Library.

Levett, Vercueil, Grocott. (2006). Resuscitation Fluids in Trauma, part I: why give fluid and how to give it. Trauma. (8): 47-53.

Mark, Paul E., Joseph Varon and Todd Trask. (2002). Critical Care Review: Management of Head Trauma. Chest Journal: 122:699-711.

Martin, Gregory S, MD, MS. An Update on Intravenous Fluids. (2005). Diunduh dari

http://cme.medscape.com/viewarticl e/503138. Diakses tanggal 10 November 2012.

Mulyono, I. (2006). Jenis-jenis Cairan, dalam Symposium of Fluid and Nutrition Therapy in Traumatic Patients. Bagian Anestesiologi FK UI/RSCM: Jakarta.

Procaccio, F., N. Stocchetti, G. Citerio, M. Berardino, L. Beretta, F. Della Corte, D. D'avella, G.L. Brambilla, R. Delfini, F.Servadei, G. Tomei. (2000). Guidelines for the treatment of adults with severe head trauma (part 1): initial assessment; evaluation and pre-hospital treatment; current criteria for hospital admission; systemic and cerebral monitoring. Journal of Neurosurgical Sciences. 44: 1-10.

Rudra, A., Chatterjee, S., Sengupta, S., Wankhade, R., Sirohia, S., et all. (2006). Fluid Resuscitation in Trauma. Indian Journal of Critical Care Medicine 10. 4 (Oct-Dec): 241249.

South Thames Retrieval Services (STRS). (2011). Hypertonic Saline. Diakses pada 20 November 2012, 23.00 WIB.

Tonessen AS. (1990). Crystalloids and Colloid. in Miller, RD., Anesthesia, Ed 3 ${ }^{\text {rd }}$, Vol. 2. Churchill Livingstone. $\mathrm{p}: 1439-1465$.

Vercueil, Levett, Grocott. (2006). Resuscitation Fluids in Trauma, part II: which fluid should I give. Trauma (8): 111-121. 